\title{
Evaluation of Development Planning in Kemuning Lor Village, Arjasa District, Jember Regency
}

\author{
Sumadi Sumadi ${ }^{1, *}$, Oryza Ardhiarisca ${ }^{2}$, Rahma Rina Wijayanti $^{3}$, Rediyanto Putra ${ }^{4}$ \\ 1, 2, 3 Public Sector Accounting Study Program, Politeknik Negeri Jember, Indonesia \\ ${ }^{4}$ Accounting Study Program, Faculty of Economics and Business, Universitas Negeri Surabaya, Indonesia \\ ${ }^{*}$ Corresponding author. Email: sumadi@polije.ac.id
}

\begin{abstract}
This study aims to determine and evaluate the development of the planning process and the achievement of the work program carried out by Kemuning Lor Village, Arjasa District, Jember Regency, East Java. The research design was qualitative research. The data used in this study were primary and secondary. They were collected through interviews, field observations and document analysis. The results showed that first, the planning process in the village was done through hamlet meetings, village meetings and then the village development planning meeting which produced Regional Medium Term Development Plan (RPJMD) and Local Government Work Plan (RKPD). The Regional Medium Term Development Plan is made for one period of leadership of the village head and there is a Village Regional Medium Term Development Plan for a three-year term. Furthermore, the Regional Medium Term Development Plan becomes the basis of the Local Government Work Plan which contains related budgets for one year. Second, the achievement of the program in Kemuning Lor village was almost 100\% absorbed. In 2020, Kasun and Kesra died, resulting in Silpa. Due to the Covid-19, there was a budget reallocation for road construction reallocated into social assistance. Finally, the planning process in Kemuning Lor Village is in line with applicable regulations, namely Permendagri No. 114 of 2014. In sum, the implementation of government in Kemuning Lor Village is in line with the applicable regulations and it needs to be carried out consistently for future periods.
\end{abstract}

Keywords: Planning, Regional Medium Term Development Plan, Local Government Work Plan, Work Program

\section{INTRODUCTION}

Indonesia had 71,074 village-level areas in 2018 [1]. The village is the lowest administrative levelled by the village head. Each village consists of community groups; Citizens Association (RW) and Neighborhood Association (RT). It aims to achieve the welfare and development of society as a whole [2].

Village development can be interpreted as an effort to improve the quality of life in order to achieve the welfare of the people living in the village [3]. It consists of three main stages; planning, implementation, and supervision which is a continuous process [4]. Village development planning is a process of the stages of activities organized by the Village Government. This activity also involves the Village Council (BPD) and community elements in a participatory manner [3]. The planning activity was initiated by the Multi Stakeholder Consultation Forum for Development Planning (Musrenbang) with the aim of preparing the Government Work Plan (RKP). RKP becomes a guideline in implementing the village development in one year and it contains an evaluation of village development in the previous year and the development of policy priorities [4].

In the village development, the government provides funds for the implementation of activities in the RKP. Therefore, it is necessary to carry out 
Village Financial Management based on the applicable regulations.

Kemuning Lor Village is located in Arjasa District, in which the highest fund limit has increased every year, starting from IDR 699,998,459 in 2016 to IDR $1,457,866,798$ in 2020 [5]. It shows a significant improvement in the village development that must be followed by an optimal, effective and efficient village financial management to achieve prosperity. Additionally, Kemuning Lor is a fostered village of State Polytechnic of Jember. It becomes a strong reason for the researchers to help create good financial planning and optimize the village.

The reference for the planning, implementation, and financial accountability process in Kemuning Lor Village is Law number 6 of 2014 concerning Villages and Minister of Home Affairs Regulation Number 114 of 2014 concerning Village Development Guidelines. However, there are still technical obstacles due to a lack of knowledge of human resources in managing the village funds.

Based on these conditions, this research will discuss the planning of the village funds, which is the initial stage of village financial management affecting the village development. This research is in line with the Research Master Plan of Politeknik Negeri Jember (Polije), researching on public governance with the theme financial planning (basic research) which has a technology readiness level (TKT) of three (3) because it is a proof of concept and or important characteristics. This research supports the research priorities of Politeknik Negeri Jember in social focus, humanities, education, arts and culture and supports the theme of the National Research Master Plan which is development studies and socio-cultural strengthening.

\section{LITERATURE REVIEW}

\subsection{Village Financial Management}

Village financial management can be interpreted as a whole activity consisting of planning, implementation, administration, reporting, and financial accountability in a village. It is carried out within one fiscal year in a transparent, accountable and participatory manner. The village head is a figure who has power in managing village funds. However, in practice, the power is delegated to village officials. It has an impact on the joint implementation of village financial management between the Village Head and the Village Financial Management Technical Officer (PTPKD) [6].

\subsection{Village Financial Planning and Budgeting}

Village financial planning is defined as village government revenue and expenditure planning in one fiscal year. Budgeting can be defined as the process of preparing a budget. The budget can be defined as a form of statement related to the estimated performance achieved in a certain period of time which financial measures can express. Public sector budgeting is a process of determining the amount of budget allocation used for each program and activity expressed in monetary units [7]. There is an integration process between village financial planning and budgeting. It is because the village financial planning process produces an output, that is, budgeting. The existence of the planning and budgeting process is proof of commitment to improve services to the community.

The main point of the village development planning process is the implementation of the MultiStakeholder Consultation Forum for Development Planning (Musrenbang) village. In village Musrenbang, village heads, village secretaries, stakeholders at the village level, and village community organizations prepare village plans to develop villages according to their potential, village needs but still in line with district development priorities. The purpose of the village Musrenbang is the preparation of the Village Government Work Plan (RKP). The implementation of Musrenbang takes place no later than June of the current budget year. The village government uses village development planning as a guide in preparing the draft RPJM (Medium-Term Development Plan) for the Village, RKP Desa, and a list of proposed RKP Villages. The Village Government is obliged to hold a participatory Village development planning deliberation [8].

\section{METHOD}

\subsection{Research Area}

The setting of the research is in Kemuning Lor Village, Arjasa District, Jember Regency. The research was conducted in Kemuning Lor Village Head Office, approximately 5.4 Kilometers from the Jember State Polytechnic.

\subsection{Data Types and Sources}

This research used descriptive qualitative research with two types of data, primary data and secondary data. The primary data comes from interviews with informants. The informants involved in this study comprehend the village financial planning and budgeting processes such as the head of the village, 
the secretaries, the head of the village council, village community empowerment, and community representatives. The secondary data were taken from documents that can support the analysis in this study. The informants of this study they are:

1. Informant 1 is an employee of the governance section at the Kemuning Village office

2. Informan 2 is an employee of the planning department at the Kemuning Village office

3. Informan 3 is an employee of the administration section at the Kemuning Lor Village office

\subsection{Data collection technique}

This study collects data using several techniques. The data collection techniques in this study are as follows.

\subsubsection{Observation}

This method aims to determine the conditions and important information at the research setting to determine the next action that should be taken.

\subsubsection{Interview}

The aim of conducting the interview is to obtain information on village financial planning and budgeting.

\subsubsection{Documentation}

It aims to collect data related to village financial planning and budgeting.

\subsection{Data Analysis}

Every research requires a standard to find out the truth of the research results. In this study, the researcher examined the validity of the data by using a credibility test. The procedures of examining the credibility of the data are as follows:

\subsubsection{Triangulation}

It refers to checking data from various sources in various ways, and at various times. This study used source triangulation to test the credibility of the data by checking the data obtained through several sources. The data were then described, categorized, which views are the same, which are different, and which are specific.

\subsubsection{Member Checking}

The process of checking the data obtained by the researchers to the informants is used to find out whether the data obtained is appropriate with the data given by the informants. The member checking was carried out after collecting the data, or after obtaining a finding (conclusion). If the data found by the researchers were approved by the informants, then it can be said that the data are valid (credible/ or trustworthy). However, if the informants did not approve the data obtained, the researchers needed to discuss it with the informants again. After the data were approved, the informants were asked to sign to make it more identical, proving that the researchers had done a member checking.

\section{RESULTS}

\subsection{Village Planning Process}

\subsubsection{Village Medium Term Development Plan}

Village planning consists of medium and shortterm planning; medium-term planning is covered in the Village RPJM, while short-term planning is in the Village RKP. In the planning process, a deliberation called the Musrenbangdes was carried out, producing the Village RPJM draft output. Furthermore, the RPJMDes draft will be approved by the village head and the BPD. The output of the deliberation is in the form of a village regulation regarding the Village RPJMD. This RPJM is a village development plan for one period of leadership of the Village Head, six years. Based on Permendagri No. 114 of 2014, the RPJMDes contains the vision and mission of the village head and the direction of village policies. Informant 2 conveyed,

"The RPJMDes was made from the beginning of the elected village head, simultaneously all the districts with only different dates. Starting from the preparation, the BPMD has determined the month for the RPJMdes deliberation; the subdistrict has chosen the date. The village just follows the regulation; every village takes a turn, all Muspika come."

Based on Permendagri No. 114 of 2014, there are four areas of the implementation of village development, those are village administration, village development, community development, and community empowerment. The activities carried out in Kemuning Lor Village cover infrastructure, community empowerment, namely women and agriculture which are feedback from the community as conveyed by Informant 1:

"Taken from the aspirations, from $R T$ and $R W$, community leaders. Both infrastructure, women's empowerment and agriculture. The infrastructure is such as damaged roads or culverts. What kind of women's empowerment is in here? Since it's a 
tourist village, what's the potential? so mothers do not just wait for their husbands, the same thing is for the widows. In agricultural sectors here, most of the people are farmers or farm laborers. There are a coffee contract and fertilizer assistance here. Sometimes fertilizer is rare. What becomes the priority for farmers? For instance, in the farmer's group, is there any help? such as fertilizer assistance."

The village head organizes the preparation of the RPJMDes and is obliged to include the village community, as stated in Permendagri No. 114 of 2014. It has been carried out by the Kemuning village government as stated by Informant 1:

"The process starts from Musdus, Musdes, Musrenbang, RKPDes, RPJMDes is basically from Musdus then it becomes RKPDes (short term, every year), RPJMDes every three years. The process of compiling the RPJMDes is from the Musdus, gathering $R T, R W$, community leaders, youth leaders, some of the female cadres who have potential in their hamlet, infrastructure, and women's empowerment as skills, Musdes deal, village-level progress. At the end of the year, Musrenbangdes is held by inviting a large scope, all $R T, R W$, community leaders, youth leaders, religion, $40 \%$ female figures, more than 200 cadres (1 year, prioritized, forming RKPDes, designed, formed APBDes, which one is the priority? because of the covid-19 pandemic, dd assistance was budgeted from village funds, the ones who receive it is the real elderly people."

Based on Permendagri No. 114 of 2014, the team for the Village RPJMD consists of the village head as the coach, the village secretary as the chairman, the head of the community empowerment institution as the secretary, and members from the village apparatus, community empowerment institutions, and other community elements. It was also carried out in Kemuning Lor as stated by Informant 1:

"RT, $R W$ who are invited are the same between Musdus and Musren, only if the hamlets are different, all BPD per hamlet to BPD. In BPD, it must be in the region; for each hamlet, there must be BPD per region. Why the Musrenbangdes is not more than 200. If we invite all of them, it is more than 250. How many BPD, how many tools, $60 R T R W$, community leaders. If one is invited, it will not be in sync. Then all are invited."

The community at the Musrenbangdes activity was also given an invitation to participate in giving aspirations. Community participation in
Musrenbangdes activities is very enthusiastic. It was conveyed by Informant 3:

"People come when they are invited. They must come, about $90 \%$ of the quorum, but usually more. Generally, the meeting has separate points and is attended by the sub-district. The sub-district also brings the civil service police unit or anyone else."

Based on Permendagri No. 114 of 2014, the RPJMDes drafting team carried out activities such as aligning district/city development policy directions, assessing village conditions, drafting the RPJMDesa draft, and finalizing the RPJMDesa draft. The second stage, the assessment of village conditions, aims to consider objective conditions with a number of activities that include disseminating village data, extracting community ideas, and compiling reports on the results of the assessment of community conditions. In community excavation, aspirations from the community are needed to solve village problems or develop village potential. It was conveyed by Informant 2 :

"Bringing in all representatives of citizens, $R T$ and $R W$, community leaders. BPD accommodates aspirations. What the residents put forward; we will accommodate the aspirations. Not all submissions are covered, just the priority. It was accommodated, sorted out which one was the urgent one. It was based on priority and ADD. Currently focusing on irrigation, beauty, rice fields, small rivers, and irrigation. This priority is a directive from the Regency."

The exploration of community ideas is carried out in a participative way by involving all elements of the village community as a source of data and information. Village community involvement can be done through hamlet meetings or special meetings for community elements. It was stated by Informant 2 :

"The deliberation comes from RT, Hamlet, Village, Sub-District, District level; Musdus in each Hamlet, its Musdes was held in the village. The results of the Musdus were brought to the village. There are $R T, R W$, representatives of residents who give aspirations."

The implementation of the Musdes in Kemuning Lor Village has no problems. It is because village officials have already come to the location, as stated by Informant 3:

"So far, there have been no problems. Before the Musdes was held, they had come to the location, there was an agreement, whether it met the criteria or not" 
The RPJMDesa drafting team will then compile a report on the results of the assessment towards the condition of the village as outlined in the official report and attached with documents: the data that have been synchronized, the plan data of district/city development program that will belong to the village, the plan data of rural area development program, and recapitulation of proposals for village development activities from hamlets and community groups. It was mentioned by Informant 2:

"RPJMDes contains the RAB (budget plan), what programs are included. Besides, it is also related to $A D D, D D, D B H, P A D . "$

The RPJMDes drafting team submits the results of the village condition assessment to the village head. Then, the village head submits to the BPD to prepare a village development plan through village meetings. After that, the BPD holds a village meeting to discuss and agree on the report on the results of the village assessment. The results of the agreement in the village meeting will guide the village government in preparing the RPJMDesa. As stated by Informant 1:

"Musdes implemented depends on the needs. The APBDes planning process from deliberation, discussed with the BPD, the name is musdes between the village head and the BPD without exception. We discuss what to prioritize...."

Furthermore, the RPJMDes drafting team compiles the RPJMDes draft based on the minutes of the preparation of the village development plan through village deliberations. The RPJMDes drafting team prepares an official report on the results of the RPJMDes drafting, which is attached by the RPJMDesa draft document to the village head. The village head checks the RPJMDesa draft document that the team has prepared. Then the team made changes based on the direction of the village head. A village development planning meeting is held when the village head has approved the RPJMDes draft. The Musrenbangdes activity aims to discuss and agree on the draft RPJMDes. The village government, BPD, and community elements attended the Musrenbangdes. As stated by Informant 3:

"Everyone coming is the same except, for the musdus, it covers the head of the hamlet, RT, RW, community leaders, and even then representatives.

Musdes activities in Kemuning Lor Village are usually carried out at night because the Musdes participants spend more time at night. Informant 2 said:
"People are enthusiastic about the development. The meetings are usually in the evening because people have a lot of time. In the afternoon, the PKK usually meet."

The process of planning the work program of Kemuning Lor Village starts from a village meeting (Musdes), then the results are continued to the Village Development Planning Deliberation (Musrenbangdes). Musrenbangdes is held once a year. The steps of the planning process were mentioned by Informant 3, covering:

"The first is Musdes, then Musrenbangdes. The results from the Musdes are discussed in the Musrenbangdes. It was held once in a year."

It is supported by the opinion of Informant 2 regarding the process of conveying aspirations from the community as well as the follow-up of programs that have not been realized. It will be submitted for the following year:

"We give a blank paper; for example, the lowest hamlet wants to submit anything they want to submit. Later it will be delivered at the village development planning meeting. All the proposals are read out. We'll prioritize."

"In one hamlet, for example, there are two projects that are not covered, God willing, next year for our homework, according to the available funds. For example, now it is not realized, it can enter next year, enter the longterm RPJMDes."

When the Musdes was conducted, the implementation of the Musrenbangdes did not have any problems as stated by Informant 3:

"There are no problems when our meeting is actually finished, we just have to submit, but before the meeting, there are usually proposals, formal proposals."

The results of the Musrenbangdes agreement are stated in the official report. After the RPJMDes drafting team made improvements to the RPJMDes design document based on the village development planning agreement, the village head then prepared a draft village regulation on the RPJMDes. The village regulation draft on the Village RPJMD is discussed and approved by the village head and the BPD to be stipulated as a village regulation on the Village RPJMD. 


\subsubsection{Village Government Work Plan (RKPDesa)}

Based on Permendagri No. 114 of 2014, RKPDes is an elaboration of RPJMDes for one year. The RKPDes contains the village economic framework by taking into account the updated funding framework, priority village development programs, work plans, and funding as well as forward estimates, either implemented directly by the village government or pursued by encouraging community participation by referring to the Regional Government Work Plan (RKPD) and RPJMDes. As mentioned by Informant 1:

"The process of Musdus, Musdes, Musrenbang, RKPDes, RPJMDes basically comes from the new Musdus, then RKPDes (short term, every year), RPJMDes every 3 years. The process of compiling the RPJMDes from the Musdus,

"A piece of paper is given to each Hamlet, what is being prioritized in the hamlet either infrastructure, empowerment, irrigation. After Musrenbangdes, the RPJMDes appears, there are 2 RPJMDes (medium-term; three years and long term; six years) during the village head office."

Permendagri No. 114 of 2014 states that the village government prepares the RKPDes in line with the information from the district/city local government relating to village indicatives and government activity plans, the provincial government, and district/city local governments. This RKPDesa began to be compiled by the village government in July of the current year. The village regulations determine RKPDes no later than the end of September of the current year to become the basis for determining APBDes. It was stated by Informant 2:

"There is already a ceiling; that is why every hamlet is not the same to get ADD. It is afraid that it will not be enough. The amount of ADD fits the hamlet's needs, so each hamlet is not the same, depending on what is being prioritized."

It is supported by Informant 1, who said that composing village regulations (Perdes) was done after composing the regent's regulations:

"Wait for the Perbup to come down, when Perbup comes down, how many millions of $A D D$, how many millions of DD disbursed to the village, how it was spent was up to the village, referring to RKPDs, it should be the same, there are some guidelines."

The village head prepared the RKPDes by involving the community. The preparation of the
RKPDes was carried out with activities including the preparation of village development plans, formation of the RKPDes drafting team, scrutiny of village indicative ceilings and alignment of village entry programs/activities, the re-examination of village RPJM documents, RKPDes drafting, preparation of RKPDes through Musrenbangdes, establishment of RKPDes, changes of RKPDes and submissions of the proposed RKPDes. Informant 1 mentioned:

"RKPDes absorbs the aspirations of the community, from the Musrenbangdes, all hamlets without exception. Musdus is a village meeting; only community leaders are there. After that, the Musrenbangdes level, then the determination of the APBDes at Musdes. Musdes refers to what is being prioritized. Only the BPD and village officials were invited, which one becomes APBDes then which one was distributed. Just like preschool teachers' salary, right now due to the Covid-19 pandemic, they asked for an additional fee; Well, the village, village officials, BPD should be in APBDes."

The village head submitted a list of proposed RKPDesa to the regent/mayor through the subdistrict head no later than December 31 of the current year. The list of proposed RKPDes becomes the subject of discussion in Musrenbang sub-district and district/city. The regent/mayor informs the village government about the results of the discussion. The list of proposed RKPDes after the Musrenbang is held in the sub-district no later than July of the next budget.

\section{CONCLUSION}

The research activities showed that the planning process in the village was done through hamlet meetings, village meetings, and then Musrenbangdes, which produces RPJMDes and RKPDes. The RPJMDes was made for one period of leadership of the village head. Furthermore, there is a Village RPJMD for a three-year term. Furthermore, the RPJMDes becomes the basis of the RKPDes, which contains related budgets for one year. The planning process in Kemuning Lor Village is in line with applicable regulations, namely Permendagri No. 114 of 2014.

The results of this study can be used as a reference source for future research while still taking into account the limitations contained in this study. The first limitation of this research is that the number of informants used in the study is limited to 3 (three) people due to the limited time of conducting the research which ultimately limits the number of informants involved in this study. Therefore, further 
research is expected to increase the number of informants relevant to the process of making village development plans. The second limitation of this research is that some confidential data cannot be used to support research data. Future research is expected to be able to find sources of data supporting relevant research results and publishable.

\section{ACKNOWLEDGMENTS}

The authors would like to thank those who have helped in the process of completing this research. First, the authors would like to thank the Jember State Polytechnic for providing support for the implementation of this research. Second, the authors would like to thank the Kemuning Lor village officials who have been willing to accept and give permission to carry out the research. Third, the authors would like to thank other parties who helped either directly or indirectly in the process of completing this research.

\section{REFERENCES}

[1] Badan Pusat Statistik, "Jumlah Desa Menurut Provinsi dan Kelurahan,” 2018. [Online]. Available:

https://www.bps.go.id/dynamictable/2015/09/18 00:00:00/906/jumlah-desa-kelurahan-menurutprovinsi-dan-letak-geografi-2003---2018.htm . [Accessed: 09-Feb-2021].

[2] R. Kurnia, Panduan RT dan RW. Jakarta: Bee Media Pustaka, 2019.

[3] Menteri Dalam Negeri, Permendagri Nomor 114 Tahun 2014 tentang Pedoman Pembangunan Desa. Indonesia, 2014.

[4] R. Yabbar and A. Hamzah, Tata Kelola Pemerintah Desa. Surabaya: Pustaka, 2015.

[5] Kementerian Desa, "Sistem Informasi Desa." .

[6] R. P. Baihaqi, Sari and D. Asmawanti, "Proses Perencanaan dan Penganggaran Keuangan Desa. (Studi di Desa-Desa Kecamatan Giri Mulya Kabupaten Bengkulu Utara)," Akuntansi, vol. 7, no. 1, pp. 61-76, 2017.

[7] Mardiasmo, Akuntansi Sektor Publik. Yogyakarta: Andi Offset, 2019.

[8] Pemerintah Republik Indonesia, Peraturan Pemerintah Nomor 47 Tahun 2015 tentang Peraturan Pelaksanaan Undang-Undang Nomor 6 Tahun 2014 Tentang Desa. 2015. 